Marija Mihajlović1 ${ }^{*}$, Jelena Petrović ${ }^{1}$, Mirjana Stojanović ${ }^{1}$, Jelena Milojković ${ }^{1}$, Zorica Lopičić ${ }^{1}$, Marija Koprivica', Časlav Lačnjevac ${ }^{2}$

${ }^{1}$ Institute for Technology of Nuclear and Other Mineral Raw Materials, Belgrade, Serbia, ${ }^{2}$ University of Belgrade, Faculty of Agriculture, Belgrade, Serbia

Review paper

ISSN 0351-9465, E-ISSN 2466-2585

UDC:628.161.2

doi:10.5937/ZasMat1603488M

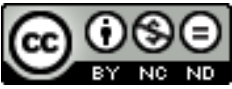

Zastita Materijala 57 (3)

488 - 495 (2016)

\title{
Hydrochars, perspective adsorbents of heavy metals: - A review of the current state of studies
}

\begin{abstract}
As an alternative to dry pyrolysis, hydrothermal carbonization has been proposed as a promising route for conversion of different wastes into biofuels, adsorbents and specific chemicals. Herein, the application of a wide range of waste biomasses as precursors to obtain hydrochars - efficient adsorbents of heavy metals from wastewaters, using hydrothermal conversion, was reviewed. The efficiency of biosorbents has been discussed with respect to the structural characteristics, reaction parameters, sorption capacities and mechanisms, as well as proposed methods of improving hydrochar's surface reactivity. Altogether, biosorption with hydrochars has been identified as a proper alternative to the existing technologies applied for the removal of toxic metal ions from wastewater streams.
\end{abstract}

Keywords: hydrochar, heavy metals, adsorption, activation

\section{INTRODUCTION}

Large-scale technological activities, primarily mining and metal processing, generate significant quantities of industrial effluents. The increased release of heavy metals into watercourses has damaging effects to biota worldwide [1]. Lead, cadmium, cobalt, nickel, etc., can affect the formation of blood cells, cause malfunctions in the liver, kidneys, the circulatory system, and the movement of nerve signals. Some heavy metals are highly cancerogenic. However, the environmental contamination and human exposure to toxic metals have dramatically increased during the past century [2]. Along with the persistence against chemical and biological degradation, heavy metals have high environmental mobility and ability for bioaccumulation in the food chain [3].

Therefore, nowadays, more attention is directed towards discovery of more efficient wastewaters treatments. Conventional wastewater treatments have proved to be more inimical than beneficial [4]. Hence, in the past two decades raise of the environmental awareness led to the development of new, eco-friendly technologies for wastewater purification. This period can be considered as the beginning of biosorption [1-8].

\footnotetext{
${ }^{*}$ Corresponding author: Marija Mihajlović

Email: m.mihajlovic@itnms.ac.rs

Paper received: 15. 06. 2015.

Paper accepted: 19. 07. 2016.

Paper is available on the website:

www.idk.org.rs/journal
}

Utilization of different biological materials for removing pollutants from aqueous solutions has been suggested to have numerous advantages in relation to the conventional methods like selectivity, effectiveness at low concentration of pollutants, low-price, and sustainability [4]. Expended biomass sometimes can be regenerated, reused, or its effectiveness can be increased using different physical and/or chemical treatments [8-12]. Therefore, a number of raw industrial and agricultural residues have been tested as low cost sorbents of heavy metals from wastewaters [1-15]. However, a major drawback for almost all raw biosorbents is the release of organic components that may cause secondary pollution and oxygen reduction in water [16]. One of the proposed pathways of overcoming this issue is the use of different carbonization techniques of raw biomass [17].

The renaissance of research on conversion processes and their products has been driven by current world initiative of development "green" technologies to reduce global warming $[17,18]$. One of such technologies is hydrothermal carbonization (HTC) also known as wet pyrolysis. Proposed back in the early $20^{\text {th }}$ Century [19], this process, described as a simulation of the natural formation of coal, after recent studies on chemistry of the resulting products suddenly revived interest. During HTC, biomass heated between $180^{\circ} \mathrm{C}$ and $300^{\circ} \mathrm{C}$ in the closed system at autogenic pressure, undergoes a thermochemical transformation into carbonaceous solid, hydrochar (HC) [20]. The major advantage of HTC over the other two most commonly used biomass conversion technologies, 
dry pyrolysis and gasification, is that HTC does not require pre-drying of raw material, which significantly facilitates its implementation and opens up a wider field of potential feedstock. Unlike conversion by dry pyrolysis, which is limited to usage of biomass with low water content such as woods and some agricultural residues, HTC feedstock except lignocellulosic residues can be unconventional biomasses such as animal manures, sewage sludge, municipal solid waste, as well as different aquacultures [17, 20-22]. This is very important since these continuously generated wastes require proper treatment and management anyway. Furthermore, the HTC process converts record high content of carbon from biomass to the coal, with no methane or $\mathrm{CO}_{2}$ release into the atmosphere [20].

So far, HTC has been utilized on various feedstocks [10, 21-44]. The resulting $\mathrm{HC}$, created via reactions between subcritical water and biomass, is coal like solid material with specific physiochemica properties which affected its potential applications, including carbon sequestration, soil amelioration, bioenergy production, and wastewater pollution remediation $[18,20]$. Aside from the solid, this process generates larger quantities process water and smaller amount of the gaseous phase.

Although literature suggests that $\mathrm{HCs}$ are valuable resources superior to biochar [18], characterization of these materials is relatively at its beginnings. Therefore, effective utilization of $\mathrm{HCs}$ requires further investigations of the structure and underlying action mechanisms, especially when it comes to biosorption studies that are still in developing phase.

This review focuses on to date present knowledge regarding the application of $\mathrm{HCs}$ as adsorbents of heavy metals from aqueous solution with an emphasis on relevant physical and structural characteristics of the solid, biosorption potential, mechanisms of metal binding, and tailoring the structure of HCs in order to improve its adsorption abilities.

\section{PHYSICAL AND STRUCTURAL CHARACTERISTICS OF HYDROCHARS}

Feedstock types and reaction conditions (process temperature and reaction time) are main determinants affecting the $\mathrm{HC}$ resulting composition. Potential biomasses used for production of $\mathrm{HC}$, and following $\mathrm{HCs}$ characteristics are given in Table 1.

Similar to other thermochemical conversion processes, hydrothermal reconstruction of the biomass is driven by different chemical mechanisms, decarboxylation, dehydration, condensation, aromatization, etc., except that during HTC hydrolysis of biomacromolecules is determining first step [29, 30]. Free-radical mechanisms, characteristic for dry pyrolysis, are overcomed in subcritical hot water in favor of ionic reactions. Therefore, $\mathrm{HC}$ is largely formed by recondensation reactions and exhibits distinct characteristics from dry pyrolysis biochar [17].

Although in both conversion procesess solid yield decreases with the inreasing of the reaction temperature, likewise $\mathrm{H} / \mathrm{C}$ and $\mathrm{O} / \mathrm{C}$ ratios, carbon conversion eficiency is more pronounced in HTC [33]. Usually, in dry pyrolysis about $50 \%$ of the biomass carbon is converted to solids, while in HTC it is between $60-86 \%[17,21]$. By default, $\mathrm{HC}$ from waste feedstock has a correspondingly lower carbon content (Table 1).

Despite a significant carbon recovery during $\mathrm{HTC}$, in HCs only about half of carbons are aromatic [33]. This explains relatively high $\mathrm{O} / \mathrm{C}$ and $\mathrm{H} / \mathrm{C}$ ratio of $\mathrm{HCs}$ in comparison to biochars, which is attributed to the abundance of oxygenated functional groups (OFGs) such as hydroxyl, carboxylate and carbonyl group [27, 33, 34]. Hitherto, two types of structrural models have been proposed explaining physicochemical characteristics of HCs [45]. The first model proposes a structure of $\mathrm{HC}$ as a polyaromatic lignin-type matrix with a shape very similar to that of a microsphere, built of a hydrophobic-core (composed of stable oxygen groups like ether, quinone, pyrone) and a hydrophilic-shell (composed of a large number of reactive oxygen functional groups like hydroxyl/ phenolic,carbonyl,or carboxylic) [33]. The second one have revealed that most of the carbon atoms in a $\mathrm{HC}$ samples are cross-linked directly via either $\mathrm{sp}^{2}$ or $\mathrm{sp}^{3}$ type carbon groups, in a similar way to that of a furan ring structure and dominated alkyl moieties [46, 47]. Such structure has been suggested to provide the increased surface reactivity, although HCs have generally lower porosity and surface area than biochars carbonized at temperatures above $400^{\circ} \mathrm{C}$. These features are deemed to be benificial for sorption especially of positively charged contaminants such as heavy metals [16, 21, 23, 32-37].

\section{BIOSORPTION OF HEAVY METALS}

Although HCs exhibit relatively undeveloped porous structure and surface chemistry with acidic properties, high $\mathrm{O} / \mathrm{C}$ ratio of $\mathrm{HCs}$ obtained at lower HTC temperatures indicate greater abundance of surface OFGs. Therefore, the heavy metal adsorption ability of $\mathrm{HC}$ has been reported to be noteworthy [36, 48].

In recent years, there is an exponential increase in the number of studies dealing with the use of different $\mathrm{HCs}$ as adsorbents of heavy metals. Influence of various reaction parameters on the biosorption as well as results of modeling, kinetic and thermodynamic of heavy metals adsorption using $\mathrm{HCs}$ obtained from various biomasses presented so far in the literature is summarized in Table 2. 


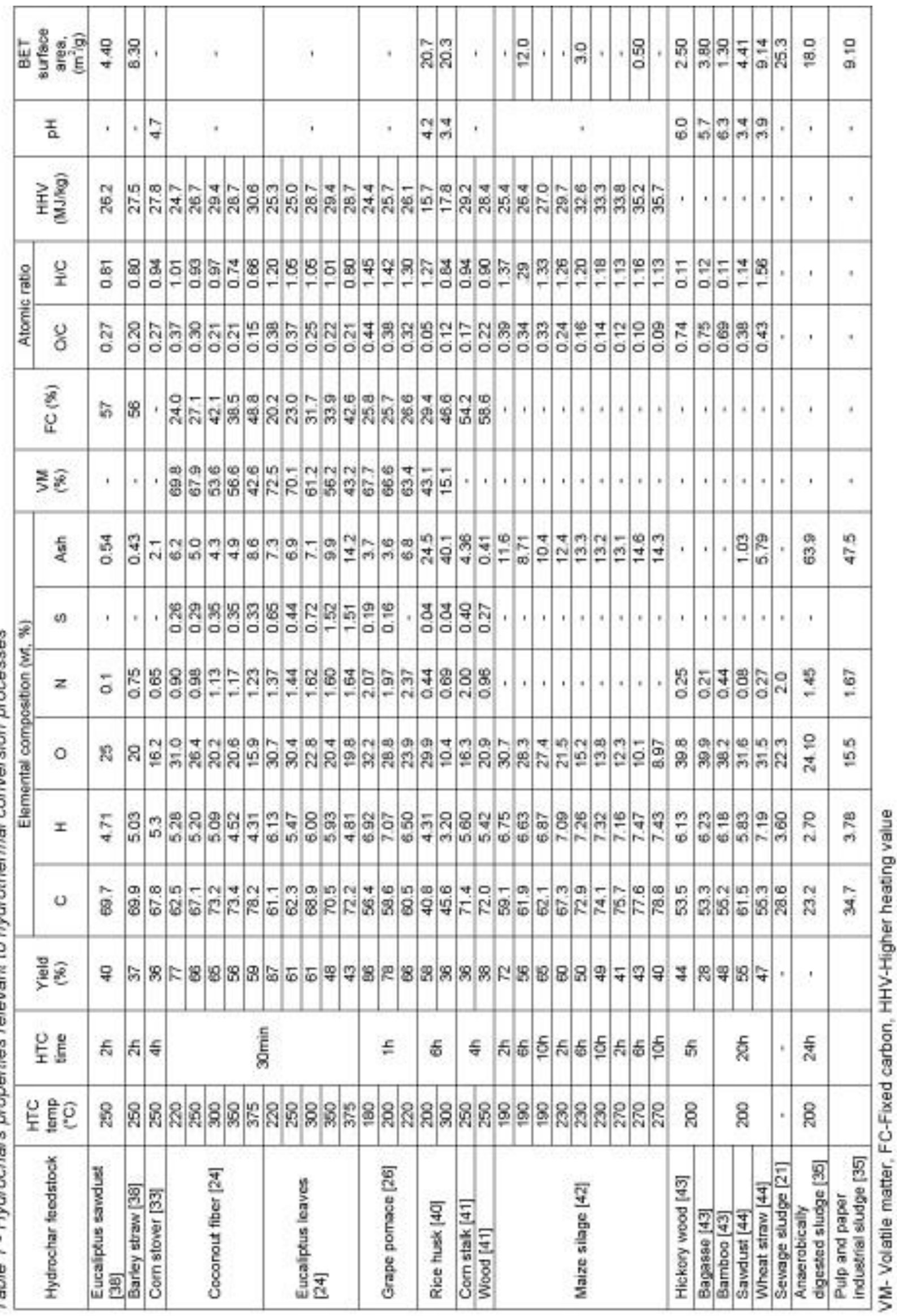


Table 2 - Adsoption parameters of HTC feedstock

\begin{tabular}{|c|c|c|c|c|c|c|c|c|c|c|}
\hline \multicolumn{3}{|c|}{ HTC } & \multicolumn{8}{|c|}{ Adsorption parameters } \\
\hline Feedstock & $\begin{array}{l}\text { Temp } \\
\left({ }^{\circ} \mathrm{C}\right)\end{array}$ & Time & Metal & $p H$ & $\begin{array}{l}\text { Temp. } \\
\left({ }^{\circ} \mathrm{C}\right)\end{array}$ & $\begin{array}{l}\text { Contact } \\
\text { time }\end{array}$ & $\begin{array}{c}q_{e q} \\
(\mathrm{mg} / \mathrm{g})\end{array}$ & $\begin{array}{l}\text { Isotherm } \\
\text { model }\end{array}$ & Kinetic model & $\begin{array}{l}\text { Thermo- } \\
\text { dynamics }\end{array}$ \\
\hline \multirow{2}{*}{$\begin{array}{l}\text { Pinewood } \\
{[16,36]}\end{array}$} & \multirow{2}{*}{300} & \multirow{2}{*}{$20 \min$} & $\mathrm{Pb}^{2+}$ & 5 & 45 & $5 \mathrm{~h}$ & 4.13 & \multirow{2}{*}{ Langmuir } & \multirow{2}{*}{ Pseudo $2^{\text {nd }}$ order } & \multirow{2}{*}{$\begin{array}{l}\text { Endotermic } \\
\text { Spontaneous }\end{array}$} \\
\hline & & & $\mathrm{Cu}^{2+}$ & 6.2 & 25 & $5 \mathrm{~h}$ & 4.46 & & & \\
\hline Rice husk [16] & 300 & $20 \mathrm{~min}$ & $\mathrm{~Pb}^{2+}$ & 5 & 45 & $5 \mathrm{~h}$ & 2.40 & Langmuir & Pseudo $2^{\text {nd }}$ order & $\begin{array}{l}\text { Endotermic } \\
\text { Spontaneous }\end{array}$ \\
\hline \multirow{3}{*}{$\begin{array}{l}\text { Switchgrass } \\
{[23,32]}\end{array}$} & \multirow{3}{*}{300} & \multirow{3}{*}{$30 \mathrm{~min}$} & $\mathrm{Cu}^{2+}$ & \multirow{2}{*}{5} & \multirow{2}{*}{23} & \multirow{2}{*}{$24 \mathrm{~h}$} & 4.00 & \multirow{2}{*}{ NM } & \multirow{2}{*}{ NM } & \multirow{2}{*}{ NM } \\
\hline & & & $\mathrm{Cd}^{2+}$ & & & & 1.50 & & & \\
\hline & & & $\mathrm{U}^{6+}$ & 6.2 & 23 & $34 \mathrm{~h}$ & 2.12 & Langmuir & NM & NM \\
\hline \multirow{2}{*}{$\begin{array}{l}\text { Prospis Africa- } \\
\text { na shell [48] }\end{array}$} & \multirow{2}{*}{200} & \multirow{2}{*}{$20 \mathrm{~min}$} & $\mathrm{~Pb}^{2+}$ & 6 & \multirow{2}{*}{22} & \multirow{2}{*}{$30 \mathrm{~min}$} & 45.3 & \multirow{2}{*}{ Langmuir } & \multirow{2}{*}{ Pseudo $2^{\text {nd }}$ order } & \multirow{2}{*}{$\begin{array}{l}\text { Endotermic } \\
\text { Spontaneous }\end{array}$} \\
\hline & & & $\mathrm{Cd}^{2+}$ & 8 & & & 38.3 & & & \\
\hline \multirow{5}{*}{$\begin{array}{l}\text { Anaerobicaly } \\
\text { digested } \\
\text { sludge[35] }\end{array}$} & \multirow{5}{*}{200} & \multirow{5}{*}{$24 \mathrm{~h}$} & $\mathrm{~Pb}^{2+}$ & 5 & \multirow{5}{*}{ NS } & \multirow{5}{*}{$24 \mathrm{~h}$} & $\sim 11$ & Sips & Pseudo $2^{\text {nd }}$ order & \multirow{5}{*}{ NM } \\
\hline & & & $\mathrm{Cr}^{3+}$ & ND & & & ND & NM & NM & \\
\hline & & & $\mathrm{Cr}^{6+}$ & 3 & & & $\mathrm{~N}$ & NM & NM & \\
\hline & & & $\mathrm{As}^{3+}$ & 3 & & & $\mathrm{~N}$ & NM & NM & \\
\hline & & & $\mathrm{As}^{5+}$ & 3 & & & $\mathrm{~N}$ & NM & NM & \\
\hline \multirow{5}{*}{$\begin{array}{l}\text { Pulp and paper } \\
\text { industrial } \\
\text { sludge [35] }\end{array}$} & \multirow{5}{*}{200} & & $\mathrm{~Pb}^{2+}$ & 5 & NS & & $\sim 11$ & Sips & Pseudo $2^{\text {nd }}$ order & NM \\
\hline & & & $\mathrm{Cr}^{3+}$ & ND & NS & & ND & NM & NM & NM \\
\hline & & $24 \mathrm{~h}$ & $\mathrm{Cr}^{6+}$ & 3 & NS & $24 \mathrm{~h}$ & $\mathrm{~N}$ & NM & NM & NM \\
\hline & & & $\mathrm{As}^{3+}$ & 3 & NS & & ND & NM & NM & NM \\
\hline & & & $\mathrm{As}^{5+}$ & 3 & NS & & ND & NM & NM & NM \\
\hline $\begin{array}{l}\text { Sewage sludge } \\
\text { [21] }\end{array}$ & NS & NS & $\mathrm{Cu}^{2+}$ & 5 & NS & $16 \mathrm{~h}$ & 15.7 & Langmuir & Pseudo $2^{\text {nd }}$ order & NM \\
\hline
\end{tabular}

ND-not detected, NM-not measured, NS-not specified, N- negligible

In two separate studies Liu et al. [36, 37] have characterized and investigated $\mathrm{Pb}^{2+}$ and $\mathrm{Cu}^{2+}$ adsorption properties of pinewood HCs. The results indicated the existence of a large amount of OFGs on the HCs surface responsible for removal capacities of 4.25 and $4.21 \mathrm{mg} / \mathrm{g}$ for $\mathrm{Pb}^{2+}$ and $\mathrm{Cu}^{2+}$, respectively. In comparison with raw pinewood, HTC increased total OFGs for $95 \%$ in resulted solid, while pyrolized pinewood biochar exhibited significantly lower OFGs content. Same authors have used $\mathrm{HC}$ of rice husk prepared under similar conditions and reported adsorption of $\mathrm{Pb}^{2+}$ from aqueous solution of $2.40 \mathrm{mg} / \mathrm{g}$. The adsorption data have been well described by Langmuir isotherm model and pseudo second order kinetics.

Similar conclusions have been reported by Elaigwu et al. [48] using $\mathrm{HC}$ prepared from microwave-assisted HTC of Prospis afficana shell for the removal of $\mathrm{Pb}^{2+}$ and $\mathrm{Cd}^{2+}$ from aqueous solution performed in batch experiments [48]. Maximum adsorption capacities for $\mathrm{HC}$ of 45.3 $\mathrm{mg} / \mathrm{g}$ for $\mathrm{Pb}^{2+}$ and $38.3 \mathrm{mg} / \mathrm{g}$ for $\mathrm{Cd}^{2+}$ were higher than that of correspondent biochars. Higher adsorption of $\mathrm{Pb}^{2+}$ in comparison to $\mathrm{Cd}^{2+}$ have been attributed to better electrostatic interaction with OFGs of the chars due to smaller ionic radius of the hydrated $\mathrm{Pb}^{2+}$.

Hydrochar produced from switchgrass have been used for removal of $\mathrm{Cu}^{2+}$ and $\mathrm{Cd}^{2+}$ from a single component solution system [23]. Reported adsorption capacities have been 4.0 and $1.5 \mathrm{mg} / \mathrm{g}$ for $\mathrm{Cu}^{2+}$ and $\mathrm{Cd}^{2+}$, respectively. The importance of the presence of OFGs on the HC surface has been again confirmed, since the powdered activated carbon has exibited lower affinity for both metals $\left(1.8\right.$ for $\mathrm{Cu}^{2+}$ and $1.5 \mathrm{mg} / \mathrm{g}$ for $\mathrm{Cd}^{2+}$ ) although it has had more than twenty times greater surface area than of switchgrass HC. Kumar et al. [32] also investigated hydrothermally treated switchgrass as an adsorbent of $\mathrm{U}^{6+}$ (Table 2). The adsorption data have been followed Langmuir isotherm model and the sorption capacity of $\mathrm{HC}$ has been reported to be $2.12 \mathrm{mg}$ of $U$ per $\mathrm{g}$ of $\mathrm{HC}$. The biosorption has been reported to be strongly $\mathrm{pH}$ dependent and towards neutral $\mathrm{pH}$ has resulted in the maximum $\mathrm{U}^{6+}$ adsorption of $4 \mathrm{mg} / \mathrm{g}$.

Anaerobically digested municipal sludge (ADS) and pulp and paper industrial sludge (INS) have been investigated in study of Alatalo et al. [35] as precursors for hydrothermal production of heavy metal sorbents. The adsorption efficiencies of both $\mathrm{HCs}$ have been reported for $\mathrm{Pb}^{2+}, \mathrm{As}^{3+}, \mathrm{As}^{5+}, \mathrm{Cr}^{3+}$ and $\mathrm{Cr}^{6+}($ Table 2). Both materials have exhibited relatively high adsorption capacity for $\mathrm{Pb}^{2+}$ (around $11 \mathrm{mg} / \mathrm{g}$ ) but much smaller for other investigated heavy metals (Table 2). The adsorption data have showed best fit to Sips isotherm model and pseudo second order kinetic model, and intraparticle diffusion have been partially involved in the adsorption process [35].

Application of $\mathrm{HCs}$ obtained from sewage sludge has also been tested as a potential sorbent of $\mathrm{Cu}^{2+}$ from aqueous solutions [21]. Removal of $\mathrm{Cu}^{2+}$ have been $15.67 \mathrm{mg} / \mathrm{g}$ at optimum experimen- 
tal conditions of $\mathrm{pH} 5$ and $70 \mathrm{mg} / \mathrm{L}$ metal concentration (Table 2). Pseudo second order of the kinetics and Langmuir isotherm model has showed best fit with the obtained experimantal data.

\section{MECHANISMS OF METAL BINDING}

All the mentioned authors, who have examined biosorption of heavy metals using different HCs, were concordant in claiming that large surface area and well developed porosity does not always indicate greater biosorption ability, and that in the adsorption, besides the structural morphology, surface functional groups perform essential role. In the main, resulting findings indicate that in the removal of heavy metals, amount of the surface OFGs are closely correlated to the adsorption capacity of HCs.

Investigating the mechanism of biochar's adsorption of $\mathrm{Pb}^{2+}$ from the solution, Wang et al. [49] have reported the possible coordination of metal ions due to surface complexation with carboxyl $(-\mathrm{COOH})$ and/or hydroxyl $(-\mathrm{OH})$ functional groups. This has been confirmed through FT-IR analysis of biochars after $\mathrm{Pb}^{2+}$ sorption. Furthermore, biochars pyrolized at higher temperatures (above $500^{\circ} \mathrm{C}$ ) have not undergone changes of the characteristic $-\mathrm{COOH}$ and $-\mathrm{OH}$ bands after sorption, probably due to the lack of these functional groups [49].The coordination between OFGs and metal ions is typically followed by the release of hydrogen ions and thus the reduction of solution $\mathrm{pH}$, which turned out to be characteristic in test solutions during biosorption of metals with HCs [50]. Similar mechanism for $\mathrm{Pb}^{2+}$ sorption with switchgrass $\mathrm{HC}$ has been proposed by Regmi et al. [23].

In the latter study, FT-IR spectra and NMR analysis have showed that more than $45 \%$ of the functional groups of switchgrass HCs are aromatic carbons [23]. The aromatic $\pi$ - system behaves as an electron donor, and this feature increases with the number of associated rings [51]. Therefore, another proposed mechanism of metal binding assumes the possibility of establishing a cationic $\pi$ - interaction between the metal and aromatics in chars. FT-IR analysis of biochars conducted by Wang et al. [50] have revealed changes in aromatic $\mathrm{C}=\mathrm{C}$ and $\mathrm{C}=\mathrm{O}$ vibrational bands before and after $\mathrm{Pb}^{2+}$ sorption, implying that $\mathrm{Pb}^{2+}-\pi$ interactions might be responsible for metal binding together with the coordination of the d-electron metal to the $\mathrm{C}=\mathrm{C}$ ( $\pi$ - electron) bond of the unsaturated and aromatic systems [52].

In studies of Lima et al. [53] and Mohan et al. [54], the adsorption of heavy metals on broiler litter and alfalfa stems biochars, and pellets from fired coal fly ash was predominantly attributed to ion exchange mechanism. Similar conclusion have reported Lu et al. [55] in whose study FT-IR analysis have showed the possible presence of ion-exchange between $\mathrm{Pb}^{2+}$ and cations containing functional groups $\left(\mathrm{R}-\mathrm{O}-\mathrm{M}^{+}\right.$or $\left.\mathrm{R}-\mathrm{COO}-\mathrm{M}^{+}\right)$. This type of mechanism have also suggested by Regmi et al. [23] although that mechanisms of surface complexation and cationic $\pi$ - interaction could not be neglected.

However, in the literature that deals with the phenomenon of heavy metal sorption on $\mathrm{HCs}$, background mechanisms of metal binding are insufficiently elucidated, and therefore, further examinations regarding its relative contribution in overall adsorption process are highly needed.

\section{SURFACE ACTIVATION}

Recent advances in the synthesis of carbon materials using HTC have shown the possibility of tailoring $\mathrm{HCs}$ surface structure and chemical proprieties, thereby enhancing its efficiency as heavy metal sorbents.

The carbons derived from pine wood and rice husk HCs, after pyrolysis $\left(800{ }^{\circ} \mathrm{C}\right)$ and following $\mathrm{CO}_{2}$-activation, have exhibited significantly higher adsorption capacities for $\mathrm{Cu}^{2+}$ of 25.18 and 22.62 $\mathrm{mg} / \mathrm{g}$, respectively, in comparison to untreated $\mathrm{HCs}$ ( 4 mg/g) Table $2[36,37]$.

In the work of Xue et al. [50], batch experiments have been conducted to investigate the effect of $10 \% \mathrm{H}_{2} \mathrm{O}_{2}$ solution treatment on peanut hull $\mathrm{HC}$ to remove heavy metals. Obtained results have showed that $\mathrm{Pb}^{2+}$ sorption ability of modified HCs $(22.82 \mathrm{mg} / \mathrm{g}$ ) was twentyfold higher than that of untreated HCs $(0.88 \mathrm{mg} / \mathrm{g})$. These results have been confirmed when HCs have been used as filters in following column experiments. The activated $\mathrm{HC}$ except $\mathrm{Pb}^{2+}$ has effectively removed other heavy metals $\left(\mathrm{Cu}^{2+}, \mathrm{Ni}^{2+}\right.$ and $\left.\mathrm{Cd}^{2+}\right)$ from water flow [50].

The cold alkali activation process proposed by Regmi et al. [23] using $2 \mathrm{M} \mathrm{KOH}$ solution has been developed to enhance the porous structure and sorption properties of $\mathrm{HC}$. As it was foreseeable, activated switchgrass $\mathrm{HC}$ exhibited much higher adsorption potential for $\mathrm{Cu}^{2+}$ and $\mathrm{Cd}^{2+}$ (of 31 and $34 \mathrm{mg} / \mathrm{g}$, respectively) than untreated $\mathrm{HC}$ (of 4 and $1.5 \mathrm{mg} / \mathrm{g}$, respectively, Table 2) and activated carbon (1.8 and $1.5 \mathrm{mg} / \mathrm{g}$, respectively) [23]. Results of the same method of activation using sawdust, wheat straw and corn stalk HCs, have been reported by Sun et al. [44]. Their investigation showed that $\mathrm{KOH}$ treatment have increased the aromatic and OFGs in HCs, which resulted in more than a double efficient removal of $\mathrm{Cd}^{2+}$ from the aqueous solution (between $30.40-40.78 \mathrm{mg} / \mathrm{g}$ ) in comparison with untreated HCs (between 13.92$14.52 \mathrm{mg} / \mathrm{g})$. 
More complex process of $\mathrm{HC}$ modification, have been presented recently by Chen et al. [56] They have presented sorption performance of ultrahigh efficient and $\mathrm{Pb}^{2+}$ selective amino-functionalized $\mathrm{HC}(\mathrm{AFHC})$, synthesized via HTC of watermelon extract and ammonium hydroxide. $\mathrm{Pb}^{2+}$ removal capacity of $\mathrm{AFHC}$ has been reported to be $1000 \mathrm{mg} / \mathrm{g}$, with preserved efficiency even at lower $\mathrm{Pb}^{2+}$ concentrations. Reported results have indicated that excellent features of AFHC may be attributed to the formation and growth of rod-like hydroxypyromorphite crystals on AFHC surface, during which amino groups serves as bridges to interact with the crystal nucleus of $\mathrm{Pb}$ [56].

\section{FUTURE TENDENCIES}

Despite the still present knowledge gap between HC properties, specific utilization and environmental impact, there is growing number of studies that are nowadays focused on the generation of a variety of tailor-designed hydrophilic nanostructured carbon and hybrid materials using HTC. Although in the beginning, presented investigations suggested that HTC have a great potential as a method of conversion of residual lignocellulosic and unconventional biomasses, in the production of new generation of efficient low-cost heavy metal sorbents. These continuing experimental trials will very soon lead to an understanding of resolute $\mathrm{HC}$ traits, allowing processes to be designed to achieve the required product characteristics.

\section{Acknowledgements}

The authors are grateful to the Serbian Ministry of Education, Science and Technological Development for the financial support of this investigation included in the project TR 31003.

\section{REFERENCES}

[1] J.Milojković, M.Mihajlović, T.Šoštarić, Z.Lopičić, M. Petrović, Č.Lačnjevac, M. Stojanović (2014) Ispitivanje efikasnosti različitih sorpcionih materijala za uklanjanje $\mathrm{Cu}(\mathrm{II})$ jona iz vodenog rastvora, Zaštita materijala, 55(3), 25-31.

[2] P.B.Tchounwou, C.G.Yedjou, A.K.Patlolla, D.J. Sutton (2012) Heavy Metals Toxicity and the Environment, book Molecular, Clinical and Environmental Toxicology, Experientia Supplementum 101, Springer Basel. p. 133-164.

[3] Z. Lopičić, J.Milojković, T.Šoštarić, M.Petrović, Č. Lačnjevac, M.Stojanović (2013) Uticaj pH vrednosti na biosorpciju jona bakra otpadnom lignoceluloznom masom koštice breskve, Hemijska Industrija, 67(6), 1007-1015.

[4] J.Milojković, M.Mihajlović, M.Stojanović, Z.Lopičić, M Petrović, T.Šoštarić, M.Ristić (2014) Pb(II) removal from aqueous solution by Myriophyllum spicatum and its compost: equilibrium, kinetic and thermodynamic study, Journal of Chemical Technology and Biotechnology, 89, 662-670.

[5] J.V.Milojković , M.D.Stojanović, M.L.Mihajlović, Z.R. Lopičić, M.S.Petrović, T.D. Šoštarić, M.Đ.Ristić (2014) Compost of Aquatic Weed Myriophyllum spicatum as Low-Cost Biosorbent for Selected Heavy Metal lons, Water, Air, \& Soil Pollution, 225,1927-1932.

[6] M.Petrović, T.Šoštarić, M.Stojanović, J.Milojković, M.Mihajlović, M.Stanojević, S. Stanković (2016) Removal of $\mathrm{Pb}^{2+}$ ions by raw corn silk (Zea mays L.) as a novel biosorbent, Journal of the Taiwan Institute of Chemical Engineers, 58, 407-416.

[7] W.Wan Ngah, M.Hanafiah (2008) Removal of heavy metal ions from wastewater by chemically modified plant wastes as adsorbents - A review, Bioresource Technology, 99, 3935-3948.

[8] M.Emin, S.Dursun, M.Karatas (2009) Removal of $\mathrm{Cd}(\mathrm{II}), \mathrm{Pb}(\mathrm{II}), \mathrm{Cu}(\mathrm{II})$ and $\mathrm{Ni}(\mathrm{II})$ from water using modified pine bark, Desalination, 249, 519-527.

[9] B.Belhalfaoui, A.Aziz, E.H.Elandaloussi, M.S.Ouali, L.C.De Ménorva (2009) Succinate-bonded cellulose: A regenerable and powerful sorbent for cadmiumremoval from spiked high-hardness groundwater, Journal of Hazardous Materials, 169, 831-837.

[10] V.Benavente, E.Calabuig, A.Fullana (2015) Upgrading of moist agro-industrial wastes by hydrothermal carbonization, Journal of Analytical and Applied Pyrolysis, 113, 89-98.

[11] S.E.Bailey, T.J.Olin, R.M.Bricka, D.D.Adrian (1999) A review of potentially low-cost sorbents for heavy metals, Water Research, 33, 2469-2479.

[12] J.M.Dias, M.C.M.Alvim-Ferraz, M.F.Almeida, J.Rivera-Utrilla, M.Sanchez-Polo (2007) Waste materials for activated carbon preparation and its use in aqueous-phase treatment: a review, Journal of Environmental Management, 85, 833-846.

[13] J.F.P.Gordon McKay (1997) Equilibrium parameters for the sorption of copper, cadmium and zinc ions onto peat, Journal of Chemical Technology and Biotechnology, 69,309-320.

[14] M.Sciban, B.Radetic, Z.Kevresan, M.Klasnja (2007) Adsorption of heavy metals from electroplating wastewater by wood sawdust, Bioresource Technology, 98, 402-409.

[15] W.T.Tan, S.T.Oi, C.K.Lee (1993) Removal of Cr(VI) from solution by coconut husk, palm pressed fibers, Environmental Technology, 14, 277-282.

[16] Z.Liu, F.S.Zhang (2009) Removal of lead from water using biochars prepared from hydrothermal liquefaction of biomass, Journal of Hazardous Materials, 167, 933-939.

[17] J. A.Libra, K.S.Ro, C.Kammann, A.Funke, N.D. Berge, Y.Neubauer, M.Titirici, C. Fühner, O.Bens, J. Kern, K.Emmerich (2011) Hydrothermal carbonization of biomass residuals: a comparative review of the chemistry, processes and applications of wet and dry pyrolysis, Biofuels, 2(1), 89-124. 
[18] H.S. Kambo, A.Dutta (2015) A comparative review of biochar and hydrochar in terms of production, physico-chemical properties and applications, Renewable and Sustainable Energy Reviews, 45, 359-378

[19] F. Bergius (1931) Chemical reactions under high pressure. Nobel Foundation (Lecture Note), p. 133.

[20] A.Funke, F.Ziegler (2010) Hydrothermal carbonization of biomass: a summary and discussion of chemical mechanisms for process engineering, Biofuels, Bioproducts and Biorefining, 4,160-177.

[21] A. Spataru (2014) Master thesis, The use of hydrochar as a low cost adsorbent for heavy metal and phosphate removal from wastewater, Ghent University (http://lib.ugent.be/fulltxt/RUG01/002/166/ 590/RUG01002166590_2014_0001_AC.pdf

[22] B.M. Ghanim, D.S.Pandey, W.Kwapinski, J.J.Leahy (2016) Hydrothermal carbonisation of poultry litter: effects of treatment temperature and residence time on yields and chemical properties of hydrochars, Bioresource Technology, In Press, http://dx. doi.org/10.1016/j.biortech.2016.05.087

[23] P. Regmi, J.Moscoso, S.Kumar, X.Cao, J.Mao, G.Schafran (2012) Removal of copper and cadmium from aqueous solution using switchgrass biochar produced via hydrothermal carbonization process, Journal of Environmental Management 109, 61-69.

[24] Z.Liu, A.Quek, S.Hoekman, R.Balasubramanian (2013) Production of solid biocharfuel from waste biomass by hydrothermal carbonization, Fuel, 103, 943-949.

[25] M. T.Reza, J.G.Lynam, M.H.Uddin, C.J.Coronella (2013) Hydrothermal carbonization: fate of inorganics, Biomass Bioenergy, 49, 86-94.

[26] J.Petrović, N.Perišić, J.Dragišić Maksimović, V. Maksimović, M.Kragović, M. Stojanović, M. Laušević, M.Mihajlović (2016) Hydrothermal conversion of grape pomace: detailed characterization of obtained hydrochar and liquid phase, Journal of Analytical and Applied Pyrolysis, 118, 267-277.

[27] G.K.Parshetti, S.K.Hoekman, R.Balasubramanian (2013) Chemical, structural and combustion characteristics of carbonaceous products obtained by hydrothermal carbonization of palm empty fruit bunches, Bioresource Technology, 135, 683-689.

[28] H.S.Kambo, A.Dutta (2014) Strength storage, and combustion characteristics of densified lignocellulosic biomass produced via torrefaction and hydrothermal carbonization, Applied Energy, 135, 182-191.

[29] J.Poerschmann, B.Weiner, H.Wedwitschka, A. Zehnsdorf, R. Koehler, F. D. Kopinke (2015) Characterization of biochars and dissolved organic matter phases obtained upon hydrothermal carbonization of Elodea nuttallii, Bioresource Technology, 189, 145-153.

[30] M.Pala, I.C.Kantarli, H.B.Buyukisik, J.Yanik (2014) Hydrothermal carbonization and torrefaction of grape pomace: a comparative evaluation, Bioresource Technology, 161, 255-262.
[31] J.Petrović, M.Mihajlović, M.Stojanović, M. Stanojević, M.Petrović, J.Milojković, Č. Lačnjevac (2015) Održiva konverzija otpadne biomase primenom postupka hidrotermalne karbonizacije, Zaštita materijala, 56(2), 206-213

[32] S.Kumar, V.Loganathan, R.Gupta, M.Barnett (2011) An assessment of $\mathrm{U}(\mathrm{VI})$ removal from groundwater using biochar produced from hydrothermal carbonization, Journal of Environmental Management, 92, 2504-2512.

[33] A. B.Fuertes, M.Camps Arbestain, M.Sevilla, J. A.Maciá-Agulló, S.Fiol, R.López, R. J.Smernik, W.P.Aitkenhead, F.Arce, F.Macias (2010) Chemical and structural properties of carbonaceous products obtained by pyrolysis and hydrothermal carbonisation of corn stover, Australian Journal of Soil Research, 48, 618-626.

[34] J.Fang, B.Gao, J.Chen, A.R.Zimmerman (2015) Hydrochars derived from plant biomass under various conditions: Characterization and potential applications and impacts, Chemical Engineering Journal, 267, 253-259.

[35] S.Alatalo, E.Repo, E.Mäkilä, J.Salonen, E.Vakkilainen, M.Sillanpää (2013) Adsorption behavior of hydrothermally treated municipal sludge \& pulp and paper industry sludge, Bioresource Technology, 147, 71-76.

[36] Z.Liu, F.Zhang, J.Wu (2010) Characterization and application of chars produced from pinewood pyrolysis and hydrothermal treatment, Fuel, 89, 510-514.

[37] Z.Liu, F. Zhang (2011) Removal of copper (II) and phenol from aqueous solution using porous carbons derived from hydrothermal chars, Desalination, 267, 101-106.

[38] M.Sevilla, J.A.Maciá-Agulló, A.B.Fuertes (2011) Hydrothermal carbonization of biomass as a route for the sequestration of $\mathrm{CO}_{2}$ : chemical and structural properties of the carbonized products, Biomass Bioenergy, 35, 3152-3159.

[39] Q.Bach, K.Tran, R.Khalil, Ø.Skreiberg, G. Seisenbaeva (2013) Comparative assessment of wet torrefaction, Energy Fuels, 27, 6743-6753.

[40] D.Kalderis, M.S.Kotti, A.Méndez, G.Gascó (2014) Characterization of hydrochars produced by hydrothermal carbonization of rice husk, Solid Earth, 5, 477-483.

[41] L-P.Xiao, Y-J.Shi, F.Xu, R-C.Sun (2012) Hydrothermal carbonization of lignocellulosic biomass, Bioresource Technology, 118, 619-23.

[42] J.Mumme, L.Eckervogt, J.Pielert, M. Diakité, F.Rupp, J. Kern (2011) Hydrothermal carbonization of anaerobically digested maize silage, Bioresource Technology, 102, 9255-9260.

[43] Y.Sun, B.Gao, Y.Yao, J.Fang, M.Zhang, Y.Zhou, H.Chen, L.Yang (2014) Effects of feedstock type, production method, and pyrolysis temperature on biochar and hydrochar properties, Chemical Engineering Journal, 240, 574-578.

[44] K.Sun, J.Tang, Y.Gong, H.Zhang (2014) Characterization of potassium hydroxide $(\mathrm{KOH})$ modified 
hydrochars from different feedstocks for enhanced removal of heavy metals from water, Environmental Science and Pollution Research, 22, 16640-16651.

[45] M-M.Titirici, R.J.White, C.Falco, M.Sevilla (2012) Black perspectives for a green future: hydrothermal carbons for environment protection and energy storage, Energy \& Environmental Science, 5, 67966822.

[46] N.Baccile, G.Laurent, F.Babonneau, F.Fayon, MM.Titirici, M.Antonietti (2009) Structural characterization of hydrothermal carbon spheres by advanced solid-state MAS 13CNMR investigations, Journal of Physical Chemistry C, 113, 9644-54.

[47] X.Cao, K.S.Ro, I.M.Chappel, Y.Li, J.Mao (2010) Chemical structures of swine-manure chars produced under different carbonization conditions investigated by advanced solid-state 13C Nuclear Magnetic Resonance (NMR) spectroscopy, Energy Fuels, 25, 388-397.

[48] S.E.Elaigwu, V.Rocher, G.Kyriakou, G.M.Greenway (2014) Removal of $\mathrm{Pb}^{2+}$ and $\mathrm{Cd}^{2+}$ from aqueous solution using chars from pyrolysis and microwaveassisted hydrothermal carbonization of Prosopis Africana shell, Journal of Industrial and Engineering Chemistry, 20, 3467-3473.

[49] Z.Wang, G.Liu, H.Zheng, F.Li, H.Ngo, W.Guo, C.Liu, L.Chen, B.Xing (2015) Investigating the mechanisms of biochar's removal of lead from solution, Bioresource Technology, 177, 308-317.

[50] Y.Xue, B.Gao, Y.Yao, M.Inyang, M.Zhang, A.R.Zimmerman, K.S.Ro (2012) Hydrogen peroxide modification enhances the ability of biochar (hydrochar) produced from hydrothermal carbonization of peanut hull to remove aqueous heavy metals: Batch and column tests, Chemical Engineering Journal, 200, 673-680.

[51] M.Keiluweit, M.Kleber (2009) Molecular-level interactions in soils and sediments: the role of aromatic p-systems, Environmental Science \& Technology, 43, 3421-3429.

[52] A.Swiatkowski, M.Pakula, S.Biniak, M.Walczyk (2004) Influence of the surface chemistry of modified activated carbon on its electrochemical behaviour in the presence of lead (II) ions, Carbon, 42, 3057-3069.

[53] I.M.Lima, A.A.Boateng, K.T.Klasson (2010) Physicochemical and adsorptive properties of fastpyrolysis bio-chars and their steam activated counterparts, Journal of Chemical Technology \& Biotechnology, 85, 1515-1521.

[54] D.Mohan, C.U.Pittman, M.Bricka, F.Smith, B.Yancey, J.Mohammad, J.Steele, A. Papandreou, C.J.Stournaras, D.Panias (2007) Copper and cadmium adsorption on pellets made from fired coal fly ash, Journal of Hazardous Materials, 148 (3), 538-547.

[55] H.Lu, W.Zhang, Y.Yang, W.Huang, S.Wanga, R.Qiu (2012) Relative distribution of $\mathrm{Pb}^{2+}$ sorption mechanisms by sludge-derived biochar, Water Research, 46, 854-862.

[56] Y.Chen, J.Che, S.Che, K.Tian, H.Jiang (2015) Ultrahigh capacity and selective immobilization of $\mathrm{Pb}$ through crystal growth of hydroxypyromorphite on amino-functionalized hydrochar, Journal of Materials Chemistry A, 3, 9843-9850.

\title{
IZVOD
}

\section{HIDROČAĐI, PERSPEKTIVNI ADSORBENTI TEŠKIH METALA: - PREGLED AKTUELNIH PRAVACA U ISTRAŽIVANJIMA}

\begin{abstract}
Kao alternativa pirolizi, hidrotermalna karbonizacija je predložena kao perspektivan pravac konverzije širokog spektra otpadnih biomasa u biogoriva, adsorbente i specifične hemikalije. $U$ ovom preglednom radu predstavljena su aktuelna istraživanja primene različitih otpadnih biomasa, kao prekursora za dobijanje hidročađi - efikasnih adsorbenata teških metala iz otpadnih voda postupkom hidrotermalne konverzije. Efikasnost biosorbenata je diskutovana u odnosu na strukturne karakteristike, reakcione parametre, sorpcione kapacitete i mehanizme, kao i predložene metode poboljšanja površinske reaktivnosti hidročađi. Sveukupno, biosorpcija hidročađima je identifikovana kao dobra alternativa konvencionalnim tehnologijama uklanjanja toksičnih metalnih jona iz otpadnih voda.
\end{abstract}

Ključne reči: hidročađi, teški metali, adsorpcija, aktivacija.

Pregledni rad

Rad primljen: 15. 06. 2016.

Rad prihvaćen: 19. 07. 2016.

Rad je dostupan na sajtu: www.idk.org.rs/casopis 